NBER WORKING PAPER SERIES

\title{
TECHNOLOGY SHOCKS AND MONETARY POLICY: ASSESSING THE FED'S PERFORMANCE
}

\author{
Jordi Galí \\ J. David López-Salido \\ Javier Vallés \\ Working Paper 8768 \\ http://www.nber.org/papers/w8768 \\ NATIONAL BUREAU OF ECONOMIC RESEARCH \\ 1050 Massachusetts Avenue \\ Cambridge, MA 02138 \\ February 2002
}

We thank Lucrezia Reichlin, Bob King, and an anonymous referee for helpful comments. We have also benefitted from comments by seminar participants at the Banco de España, and the Insead-CEPR Macroeconomics Workshop. Galí wishes to thank the Banco de España for its generous financial support and hospitality. The views expressed herein are those of the authors and not necessarily those of the National Bureau of Economic Research or the Banco de España.

(C) 2002 by Jordi Galí, J. David López-Salido and Javier Vallés. All rights reserved. Short sections of text, not to exceed two paragraphs, may be quoted without explicit permission provided that full credit, including (C) notice, is given to the source. 
Technology Shocks and Monetary Policy: Assessing the Fed's Performance

Jordi Galí, J. David López-Salido and Javier Vallés

NBER Working Paper No. 8768

February 2002

JEL No. E31, E58

\begin{abstract}
The purpose of the present paper is twofold. First, we characterize the Fed's systematic response to technology shocks and its implications for U.S. output, hours and inflation. Second, we evaluate the extent to which those responses can be accounted for by a simple monetary policy rule (including the optimal one) in the context of a standard business cycle model with sticky prices. Our main results can be described as follows: First, we detect significant differences across periods in the response of the economy (as well as the Fed's) to a technology shock. Second, the Fed's response to a technology shock in the Volcker-Greenspan period is consistent with an optimal monetary policy rule. Third, in the pre-Volcker period the Fed's policy tended to over stabilize output at the cost of generating excessive inflation volatility. Our evidence reinforces recent results in the literature suggesting an improvement in the Fed's performance.
\end{abstract}

\author{
Jordi Galí \\ J. David López-Salido \\ Javier Vallés \\ CREI \\ Ramon Trias Fargas 25 \\ Banco de España \\ Banco de España \\ 08005 Barcelona \\ Spain \\ and NBER \\ jordi.gali@econ.upf.es \\ www.econ.upf.es/ gali
}




\section{Introduction}

Since the seminal work of Taylor (1993), many macroeconomists have shifted their attention to the analysis of the endogenous component of monetary policy, and its role in shaping the responses of nominal and real variables to different shocks. The contribution of the present paper to that research program is twofold. First, we study the behavior of the Federal Reserve (Fed) in response to a specific source of fluctuations: technology shocks. Second, we evaluate the extent to which that policy response approximates the optimal one, using a standard dynamic sticky price model as a reference framework. ${ }^{1}$

We provide evidence on the economy's response to a technology shock that is based on a structural VAR, estimated using U.S. quarterly data for the period 1954-1998. Following the strategy adopted in Galí (1999), we identify a technology shock as the only source of the unit root in labor productivity. We analyze the estimated dynamic responses of a number of real and nominal variables to that shock, and assess how the observed Fed reaction may have influenced the economy's response. Furthermore, and motivated by recent evidence pointing to significant changes over time in the Fed's monetary policy rule, we analyze the differences across two subperiods: the pre-Volcker period and the more recent Volcker-Greenspan era. ${ }^{2}$

Our theoretical analysis focuses on three alternative monetary policy rules. First, we derive and characterize the optimal policy. In the context of our model that policy is the one that fully stabilizes prices. Second, we derive the equilibrium responses to a technology shock of a number of variables under such a rule, and compare those responses to the ones generated by two alternative specifications of monetary policy: a simple Taylor rule and a constant money growth rule. We then confront the three sets of theoretical responses with the empirical ones, and try to ascertain which rule-if any- provides a better approximation to the systematic response of the Fed to the

\footnotetext{
1 Dotsey (1999) emphasizes the role of the systematic component of monetary policy in determining the economy's response to any type of shock.

2 See, e.g. Taylor (1999), Judd and Rudebusch (1999), and Clarida, Galí and Gertler (2000) for evidence of a regime change around the time Paul Volcker became the Fed's chairman.
} 
supply shocks under consideration.

Our main results can be summarized as follows. First, we detect significant differences across periods in the response of interest rates, prices, and output to a technology shock. Second, the Fed's response to that shock in the Volcker-Greenspan period is consistent with an optimal rule. Third, in the pre-Volcker period the Fed's policy tends to overstabilize output, thus generating excessive inflation volatility. Hence, our evidence reinforces recent results in the literature suggesting an improvement in the Fed's performance.

The remainder of the paper is organized as follows. In section 2 we derive and characterize the economy's equilibrium under the three rules considered. In section 3 we present our evidence on the Fed's systematic response to technology shocks, and compare the empirical responses with the theoretical counterparts. Section 4 concludes.

\section{Technology Shocks and Monetary Policy in a Sticky Price Model}

\subsection{A Baseline Sticky Price Model}

In this section we lay out a simple version of the Calvo (1983) model with staggered price setting, which we take as a reference framework for the analysis of monetary policy. Next we describe briefly the main ingredients. ${ }^{3}$

We assume a continuum of firms, indexed by subscript $i \in[0,1]$, each producing a differentiated good with a technology

$$
Y_{t}(i)=A_{t} N_{t}(i)
$$

where $(\log )$ productivity $a_{t} \equiv \log \left(A_{t}\right)$ follows the exogenous process:

$$
\Delta a_{t}=\rho \Delta a_{t-1}+\varepsilon_{t}
$$

with $\rho \in[0,1)$. For simplicity, and given our objective, we assume that such variations in aggregate productivity are the only source of fluctuations in the economy. For the sake of simplicity, the

\footnotetext{
${ }^{3}$ A detailed derivation can be found in Woodford (1996) and Yun (1996), among others.
} 
analysis that follows ignores capital accumulation. As discussed below, most of the qualitative results stressed in the present paper as well as the implications for optimal monetary policy are not affected by that simplifying assumption.

The representative household is infinitely-lived and seeks to maximize

$$
E_{0} \sum_{t=0}^{\infty} \beta^{t}\left(\frac{C_{t}^{1-\sigma}}{1-\sigma}-\frac{N_{t}^{1+\varphi}}{1+\varphi}\right)
$$

subject to a (standard) sequence of budget constraints and a solvency condition, and where $C_{t} \equiv$ $\left(\int_{0}^{1} C_{t}(i)^{\frac{\varepsilon-1}{\varepsilon}} d i\right)^{\frac{\varepsilon}{\varepsilon-1}}$ is a consumption index and $N$ denotes hours of work.

The log-linearized Euler equation associated with the consumer's problem, combined with the market clearing condition $Y_{t}=C_{t}$, yields:

$$
y_{t}=-\frac{1}{\sigma}\left(r_{t}-E_{t}\left\{\pi_{t+1}\right\}-r r\right)+E_{t}\left\{y_{t+1}\right\}
$$

where $y_{t}$ denotes $(\log )$ aggregate output, $r_{t}$ is the nominal interest rate, $\pi_{t+1}$ is the rate of inflation between $t$ and $t+1$, and $r r \equiv-\log \beta$ represents the steady state real interest rate.

The labor market is perfectly competitive, with the labor supply schedule associated with the solution to the consumer's problem being given by $w_{t}-p_{t}=\sigma c_{t}+\varphi n_{t}$, where $w_{t}$ denotes the $(\log )$ nominal wage, $p_{t}$ is the (log) aggregate price level, and $n_{t} \equiv \log \left(N_{t}\right)$. Hence, all firms face a common real marginal cost $m c_{t}=w_{t}-p_{t}-a_{t}$. Clearing of goods and labor markets implies

$$
m c_{t}=(\sigma+\varphi) y_{t}-(1+\varphi) a_{t}
$$

Each firm faces an isoelastic demand for its product (generated by the solution to the consumer's problem), and takes the path of aggregate variables as given. If all firms adjust prices optimally each period (flexible prices), the price-marginal cost markup is common across firms, constant over time, and equal to $\frac{\varepsilon}{\varepsilon-1}$. Accordingly, $m c_{t}=-\log \frac{\varepsilon}{\varepsilon-1} \equiv m c$, for all $t$. Hence, under flexible prices, the equilibrium processes for output, employment, and the expected real rate are 
independent of monetary policy and given by:

$$
\begin{gathered}
y_{t}^{*}=\gamma+\psi a_{t} \\
n_{t}^{*}=\gamma+(\psi-1) a_{t} \\
r r_{t}^{*}=r r+\sigma \rho \psi \Delta a_{t}
\end{gathered}
$$

where $\psi \equiv \frac{1+\varphi}{\sigma+\varphi}$ and $\gamma \equiv \frac{m c}{\sigma+\varphi}$. We refer to the above equilibrium values as the natural levels of output, employment, and the real interest rate, respectively.

If, on the other hand, firms can adjust prices only infrequently, the markup (and, hence, the real marginal cost) will no longer be constant. As a result a gap between actual output and its natural level may emerge. We denote that gap by $x_{t} \equiv y_{t}-y_{t}^{*}$ and refer to it as the output gap. It follows from (3), together with the previous definition, that the output gap will be proportional the deviation of real marginal cost from its frictionless level, i.e., its level under flexible prices. Formally we have $\widehat{m c}_{t}=(\sigma+\varphi) x_{t}$, where $\widehat{m c}_{t} \equiv m c_{t}-m c$.

The exact form of the equation describing aggregate inflation dynamics depends on the way sticky prices are modeled. Here we follow Calvo (1983), and assume that each firm resets its price in any given period only with probability $1-\theta$, independently of other firms and of the time elapsed since the last adjustment. Thus, each period a measure $1-\theta$ of producers reset their prices, while a fraction $\theta$ keep their prices unchanged. In that case, the aggregation of optimal price-setting decisions can be shown to yield the familiar new Phillips curve:

$$
\pi_{t}=\beta E_{t}\left\{\pi_{t+1}\right\}+\kappa x_{t}
$$

where $\kappa \equiv \frac{(1-\theta)(1-\beta \theta)(\sigma+\varphi)}{\theta}{ }^{4}$

Finally, we can rewrite equilibrium condition (2) in terms of the output gap and the natural rate of interest:

\footnotetext{
${ }^{4}$ See, e.g., Galí and Gertler (1998) for a derivation.
} 


$$
x_{t}=-\frac{1}{\sigma}\left(r_{t}-E_{t}\left\{\pi_{t+1}\right\}-r r_{t}^{*}\right)+E_{t}\left\{x_{t+1}\right\}
$$

Equations (4) and (5), together with a specification of monetary policy (i.e., of how the interest rate is determined), describe the equilibrium dynamics of the model economy in the presence of exogenous variations in aggregate technology. Next we analyze the economy's response to such disturbances under alternative specifications of monetary policy.

\subsection{The Dynamic Effects of Technology Shocks}

In this section we consider three alternative specifications of the systematic component of monetary policy: the optimal monetary policy, a simple Taylor rule, and a constant money growth rule (henceforth, a money rule). Our analysis focuses on how the nature of that systematic policy component affects the equilibrium responses of different variables to a permanent shock to technology.

\subsubsection{Optimal Monetary Policy}

The model economy described above may be plagued by a variety of distortions (market power, valuable money, etc.). We follow a number of recent papers in the literature and maintain the assumption that all such distortions, with the exception of the existence of nominal rigidities, have already been corrected by means of appropriate non-monetary interventions. ${ }^{5} \quad$ Accordingly, the natural level of output and employment coincide with their efficient levels. In such an environment monetary policy should aim at replicating the allocation associated with the flexible price equilibrium. Hence, the monetary authority focuses on correcting a distortion that is monetary in nature. The optimal policy requires that

$$
x_{t}=\pi_{t}=0
$$

\footnotetext{
${ }^{5}$ See, e.g., Rotemberg and Woodford (1999), among others.
} 
all $t$. While the presence of other distortions (in addition to staggered price setting) may lead to deviations from the previous policy, recent analyses based on calibrated models have suggested that those deviations are likely to be quantitatively small. ${ }^{6}$

Our baseline model turns out to have a simple and appealing property: the allocation associated with the flexible price equilibrium can be exactly replicated with an appropriate policy, at least under the assumption that productivity can be observed contemporaneously by the monetary authority. Using (5), such allocation can be implemented in practice using the interest rate rule

$$
r_{t}=r r+\sigma \rho \psi \Delta a_{t}+\phi_{\pi} \pi_{t}
$$

for any $\phi_{\pi}>1 .^{7}$ Hence, the equilibrium behavior of the nominal rate $r_{t}$ (as well as the real rate $\left.r r_{t}\right)$ can be represented by the process

$$
r_{t}=(1-\rho) r r+\rho r_{t-1}+\sigma \rho \psi \varepsilon_{t}
$$

The equilibrium response of output and employment will match that of their natural levels:

$$
\begin{gathered}
\Delta y_{t}=\rho \Delta y_{t-1}+\psi \varepsilon_{t} \\
\Delta n_{t}=\rho \Delta n_{t-1}+(\psi-1) \varepsilon_{t}
\end{gathered}
$$

Thus, as in the flexible price case, a permanent technology shock leads to a proportional change in output under the optimal policy, while the sign of the response of employment depends on the strength of the wealth effect, as determined by the size of $\sigma$. The lack of strong evidence of a unit root in hours in postwar U.S. data suggests a value for $\sigma$ (and hence $\psi$ ) equal or close to one. That property motivates the calibration used below.

Notice also that the equilibrium behavior of the interest rate depends on the persistence of productivity growth. Thus, when productivity is a pure random walk $(\rho=0)$ both nominal and real interest rates remain constant.

\footnotetext{
6 See, e.g., Goodfriend and King (2001) and Woodford (2001) for an extended discussion of the case for price stability and its robustness to the presence of a variety of distortions.

7 The presence of the inflation term with a coefficient greater then unity guarantees the uniqueness of the equilibrium. See, e.g., Woodford (2000) for a detailed discussion.
} 
While the above analysis has been restricted, for the sake of exposition, to a model economy with labor as the only productive input, it is important to realize that allowing for capital accumulation would not affect the basic principle for optimal monetary policy principle emphasized above, namely, the desirability of price-level stabilization. In the presence of capital, however, the equilibrium dynamics for output, hours, and the interest rate under the optimal policy will differ somewhat from the ones derived above. In particular, their representation will include an additional state variable (the capital stock), and will correspond (by construction) to the equilibrium dynamics of a standard stochastic growth model with a nonstationary technology. ${ }^{8}$

\subsubsection{A Simple Taylor Rule}

Suppose that the central bank follows the rule

$$
r_{t}=r r+\phi_{\pi} \pi_{t}+\phi_{x} x_{t}
$$

i.e., the nominal rate responds systematically to the contemporaneous values of inflation and the output gap. This is a version of the rule put forward by John Taylor as a good characterization of U.S. monetary policy, and analyzed in numerous recent papers. ${ }^{9}$

Substituting out (6) into expressions (4) and (5) the equilibrium dynamics can be represented by the system:

$$
\left[\begin{array}{l}
x_{t} \\
\pi_{t}
\end{array}\right]=\mathbf{A}_{T}\left[\begin{array}{c}
E_{t}\left\{x_{t+1}\right\} \\
E_{t}\left\{\pi_{t+1}\right\}
\end{array}\right]+\mathbf{B}_{T} \Delta a_{t}
$$

where

$$
\mathbf{A}_{T} \equiv \Omega\left[\begin{array}{cc}
\sigma & 1-\beta \phi_{\pi} \\
\sigma \kappa & \kappa+\beta\left(\sigma+\phi_{x}\right)
\end{array}\right] \quad ; \quad \mathbf{B}_{T} \equiv \sigma \rho \psi \Omega\left[\begin{array}{l}
1 \\
\kappa
\end{array}\right]
$$

and $\Omega \equiv \frac{1}{\sigma+\phi_{x}+\kappa \phi_{\pi}}$.

\footnotetext{
8 See, e.g., King, Plosser and Rebelo (1988) and Rotemberg and Woodford (1996).

9 See Taylor $(1993,1999)$.
} 
As is well known, there exists a range of values for coefficients $\left(\phi_{x}, \phi_{\pi}\right)$ such that the equilibrium is indeterminate, giving rise to the possibility of sunspot fluctuations. If we restrict ourselves to non-negative values of $\phi_{x}$ and $\phi_{\pi}$, a necessary and sufficient condition for the previous dynamical system to have a unique stationary solution (and, hence, to have well defined responses to a technology shock) is given by ${ }^{10}$

$$
\kappa\left(\phi_{\pi}-1\right)+(1-\beta) \phi_{x}>0
$$

Under that assumption the stationary solution takes the form

$$
\left[\begin{array}{l}
x_{t} \\
\pi_{t}
\end{array}\right]=\rho\left[\begin{array}{l}
x_{t-1} \\
\pi_{t-1}
\end{array}\right]+\Gamma \varepsilon_{t}
$$

where $\Gamma \equiv\left[\Gamma_{x}, \Gamma_{\pi}\right]^{\prime}=\left[\mathbf{I}-\rho \mathbf{A}_{T}\right]^{-1} \mathbf{B}_{T}$. Given the equilibrium path for $x_{t}$ it is straightforward to solve for the corresponding trajectories of output and employment:

$$
\begin{gathered}
y_{t}=\gamma+x_{t}+\psi a_{t} \\
n_{t}=\gamma+x_{t}+(\psi-1) a_{t}
\end{gathered}
$$

with the equilibrium behavior of the nominal rate given by (6). Notice that only in the case of a random walk process for technology $(\rho=0)$, will the Taylor rule supports the optimal allocation (for $\mathbf{B}_{T}=0$, in that case).

The line with squares in Figure 1 represents the equilibrium responses of different variables to a technology shock under a simple Taylor rule. We calibrate the inflation coefficient using the value suggested in Taylor (1993), namely, $\phi_{\pi}=1.5$. The output gap coefficient $\phi_{x}$ is set to zero. ${ }^{11}$

For comparison purposes we also show the corresponding responses under the optimal policy,

\footnotetext{
${ }^{10}$ See, e.g., Bullard and Mitra (2001).

11 As argued by Galí (1999), the notion of output gap used in conventional Taylor rules does not generally correspond to the model-based concept of output gap used here. The latter, defined as the deviation of output from its natural level, is an unobservable variable, which motivates its omission from any simple rule. None of our results hinge on that assumption, however.
} 
represented by the line with triangles. The remaining parameters were set at the following values: $\sigma=1, \beta=0.99, \varphi=1, \rho=0.2$, and $\theta=0.75$.

We observe that under the assumed Taylor rule output and employment increase beyond their natural levels in response to a positive technology shock, which leads to a temporary rise in inflation. Hence, the policy response implied by the Taylor rule appears not to be sufficiently contractionary. This is reflected in the fact that the path of the real rate under that rule lies uniformly below the path associated with the optimal policy.

Notice, however, that the deviations from the optimal policy are quantitatively small. Furthermore, they could be reduced further by choosing a more aggressive response (higher values for $\phi_{\pi}$ and $\phi_{x}$ ). Yet, it should be clear that no finite values for those parameters could possibly replicate the optimal responses. The reason is straightforward: supporting the optimal response requires that prices remain stable and that the real rate increases. Accordingly, the nominal interest rate should also increase. But the rule will not generate a rise in the nominal rate unless a deviation from the optimal response occurs (in the form of positive inflation or output gap). ${ }^{12}$

\subsubsection{A Monetary Targeting Rule}

Suppose next that the monetary authority targets the rate of growth of the money supply. Formally,

$$
m_{t}-m_{t-1}=\gamma_{m}
$$

where $m$ denotes the quantity of money in circulation, expressed in logs. Henceforth, and without loss of generality we set $\gamma_{m}=0$, which is consistent with zero inflation in the steady state.

The demand for money holdings is assumed to take a conventional form:

$$
m_{t}-p_{t}=y_{t}-\eta r_{t}
$$

\footnotetext{
12 It would take setting either $\phi_{\pi}$ or $\phi_{x}$ equal to infinity to achieve the optimal allocation. Such a rule would potentially lead to huge instrument-instability: any small deviation of inflation or the output gap from zero (perhaps resulting from small measurement errors or imperfect credibility) might imply infinite changes in the rate. The lack of credibility of such a policy might be more than warranted since it would be inconsistent with the zero-bound on nominal rates.
} 
Letting $m_{t}^{*} \equiv m_{t}-p_{t}-\psi a_{t}$ we can rewrite the money demand in terms of stationary variables only:

$$
m_{t}^{*}=x_{t}-\eta r_{t}
$$

Furthermore, it follows from the definition of $m_{t}^{*}$ and (7) that

$$
m_{t-1}^{*}=m_{t}^{*}+\pi_{t}+\psi \Delta a_{t}
$$

The equilibrium dynamics are now represented by the system:

$$
\left[\begin{array}{c}
x_{t} \\
\pi_{t} \\
m_{t-1}^{*}
\end{array}\right]=\mathbf{A}_{M}\left[\begin{array}{c}
E_{t}\left\{x_{t+1}\right\} \\
E_{t}\left\{\pi_{t+1}\right\} \\
m_{t}^{*}
\end{array}\right]+\mathbf{B}_{M} \Delta a_{t}
$$

where, after letting $\Theta \equiv \frac{1}{1+\sigma \eta}$,

$$
\mathbf{A}_{M} \equiv \Theta\left[\begin{array}{ccc}
\sigma \eta & \eta & 1 \\
\kappa \sigma \eta & \beta(1+\sigma \eta)+\kappa \eta & \kappa \\
\kappa \sigma \eta & \beta(1+\sigma \eta)+\kappa \eta & 1+\sigma \eta+\kappa
\end{array}\right]
$$

and

$$
\mathbf{B}_{M} \equiv \psi \Theta\left[\begin{array}{c}
\rho \sigma \eta \\
\rho \kappa \sigma \eta \\
1+\sigma \eta(1+\rho \kappa)
\end{array}\right]
$$

The line with squares in Figure 2 represents the equilibrium responses of different variables to a technology shock, under the assumption that the central bank keeps the money supply unchanged. Again, the line with triangles displays the responses under the optimal policy.

A comparison of the responses under the two rules makes clear that, in the face of a favorable productivity shock, money targeting implies a monetary stance that is too tight: the resulting path for the real interest rate lies uniformly above the optimal one. As a consequence, output does not increase as much as would be efficient, and employment declines. 
Notice also that the nominal rate remains unchanged under constant money growth. That result, however, is not general: it hinges on our specific calibration of $\sigma$. More generally, constant money growth implies that the interest rate is given by: ${ }^{13}$

$$
r_{t}=r r+\left(\frac{\sigma-1}{1+\eta}\right) \sum_{k=1}^{\infty}\left(\frac{\eta}{1+\eta}\right)^{k-1} E_{t}\left\{\Delta y_{t+k}\right\}
$$

Hence, if utility is logarithmic in consumption, the nominal rate is constant, and independent of output dynamics. ${ }^{14}$ Furthermore, it is easy to show that constant money growth will generally lead to a suboptimal response of the economy to a technology shock. The reason is simple: the optimal response requires that $\Delta y_{t}=\psi \Delta a_{t}$ and $r_{t}=r r+\sigma \rho \psi \Delta a_{t}$, for all $t$. But the latter conditions are not consistent with (8), except for a particular configuration of parameter values. ${ }^{15}$

How significant are the deviations from the optimal responses that follow from adherence to a strict money targeting rule under our calibrated model ? The results shown in Figure 2 suggest that they are far from negligible: thus, a one percent shock to productivity leads to a change of about 150 basis points in the rate of inflation, and more than 50 basis points in employment and the output gap (the three variables remain constant under the optimal policy). On that basis one should conclude that a money targeting rule is likely to be less desirable than a simple Taylor rule, at least when technology shocks are the dominant source of fluctuations.

\section{The Fed's Response to Technology Shocks: Evidence}

This section provides evidence on the Fed's systematic response to technology shocks and its implications for U.S. output, hours and inflation. We also discuss the extent to which those responses are consistent with any of the rules considered in the previous section.

\footnotetext{
${ }^{13}$ To see this, difference the money demand equation (imposing $\Delta m_{t}=0$ ), combine it with (2), and solve the resulting difference equation forward.

14 The reader may notice the connection of that result with the literature on the liquidity effect. A detailed analysis along those lines can be found in Christiano, Eichenbaum and Evans (1997) and Andrés, López-Salido, and Vallés (1999).

15 See Galí (2000) for a more detailed analysis of the deviations from optimality implied by money targeting as well as other policy rules.
} 


\subsection{Identification and Estimation}

The empirical effects of technology shocks are determined through the estimation of a structural VAR. The latter is partially-identified: given our limited objective we do not attempt to identify sources of fluctuations other than exogenous variations in technology. Our identifying restriction is that only technology shocks may have a permanent effect on the level of labor productivity, as originally proposed in Galí (1999). That restriction is satisfied by a broad range of business cycle models, under standard assumptions.

Our VAR model contains four variables: labor productivity, hours, the real interest rate and inflation. We specify labor productivity in log first differences, in accordance with the maintained hypothesis of a unit root in that variable. Hours are measured in $\log$ deviations from a fitted linear trend. Both the real rate and inflation enter in levels. ${ }^{16}$

Our hours series is the log of total employee hours in nonagricultural establishments. Labor productivity was constructed subtracting the previous variable to the log of GDP. Both, hours and GDP were normalize by working age population. The nominal interest rate is the three-month Treasury bill rate and the price is measured with the log of the CPI. All the series used are quarterly and were drawn from CITIBASE.

Our analysis covers the sample period 1954:I-1998:III. A number of authors have argued that U.S. monetary policy has experienced important structural changes over that period. The existing evidence suggests splitting the sample into two subperiods: the pre-Volcker years and the more recent Volcker-Greenspan era. ${ }^{17}$ In addition, we remove the period 79:III-82:II from our analysis, because of the unusual operating procedures that were effective during that episode. ${ }^{18}$

Table 1 reports some summary statistics on the estimated reduced form VAR system (with four lags). The third and fourth columns of the Table report the p-values for the null that the

\footnotetext{
${ }^{16}$ We have also estimated the VAR model with first differenced hours and inflation. None of the main qualitative results reported below were affected.

17 See, e.g. Taylor (1993) and Clarida, Galí and Gertler (2000).

18 See Bernanke and Mihov (1998) for formal evidence of the idiosincracy of that period.
} 
coefficients on the dependent variable's own lags (third column), or those associated with the remaining variables (fourth column) are zero. The next two columns report the $R^{2}$ and the Durbin-Watson statistics for each equation and subsample.

In order to assess the plausibility of our identification scheme we compare our estimated technology shocks with the alternative measure constructed by Basu, Fernald and Kimball (BFK, 1998) using conventional growth accounting methods. The latter generalizes the Solow residual by allowing for increasing returns, imperfect competition, and variable input utilization rates. The BFK measure is only available until 1989 on an annual basis; hence, and for the sake of comparison, we annualize our VAR-based technology shock measure (by averaging across quarters within a calendar year), and adjust the sample period accordingly. Figure 3 displays both the VAR-based and the BFK technology shock measures. While far from being identical, the series display a strong positive comovement which is apparent in the figure, with an associated correlation coefficient of 0.59 . Given that the methodologies used to construct both series are unrelated, we view the previous evidence as reinforcing the plausibility of our identification scheme.

Next we describe the evidence on the effects of technology shocks and the associated policy response, starting with the most recent subperiod.

\subsection{The Volcker-Greenspan Era}

Figure 4 displays, for the 1982:3-1998:3 period, the estimated response of a number of variables to a positive technology shock, together with associated two standard errors confidence interval. The size of the shock is normalized to one standard deviation. The Figure also shows the corresponding impulse-responses under the optimal policy. ${ }^{19}$ Figure 5 supplements that evidence by displaying the $95 \%$ acceptance interval for the null hypothesis of a zero response of all horizons for hours and inflation, together with the estimated responses themselves. ${ }^{20}$ That null corresponds to the

\footnotetext{
19 In order to match the observed response of productivity as closely as possible, the optimal responses shown in the Figure are constructed under the assumption of a random walk process for technology, with the size of the shock chosen so that the implied long run response of productivity matches the estimated one.

20 The darker bars represent the point estimates of the impulse responses and the lighter bars represent a \pm 2 standard deviations confidence intervals.
} 
optimal policy outcome in our model.

In Figure 4, we observe an impact jump in the level of productivity of about 0.3 percent. That variable stabilizes at slightly lower level later on. The output response is of a similar magnitude and sign. As a result, hours are hardly affected by the shock even though the point estimates suggest a delayed positive effect, but one which is quantitatively very small. Similar muted responses can be observed for inflation and interest rates (both nominal and real). Thus, while the estimated impact effect on real interest rate is slightly positive, we cannot reject the null of a zero response at all horizons for both hours and inflation, as shown in Figure 5. The latter result suggests that the Fed's response to technology shocks in the Volcker-Greenspan period is consistent with the optimal one, as implied by our simple sticky price model. ${ }^{21}$

\subsection{The Pre-Volcker Period}

Figures 6 and 7 display the corresponding evidence for the pre-Volcker period (1954:I-1979:II). In Figure 6, the profile of the estimated response of productivity suggests the presence of some positive autocorrelation in its first difference, in contrast with the near random walk behavior observed in the Volcker-Greenspan period. Accordingly, the responses under the optimal policy that are also displayed in Figure 6 are based on a calibration of the technology process that seeks to mimick the estimated productivity response. ${ }^{22}$

Notice that the initial output response is slightly negative; only after five quarters the effect becomes positive and keeps building up gradually. The response of hours on impact is significantly negative and quite large; that effect is reversed only after two years. ${ }^{23}$ The existence of a large deviation between those responses and the ones associated with the optimal policy is clearly apparent. In particular, the persistent negative output gap that arises in the wake of the shock is behind the negative effect on inflation, which contrasts with the requirement of price stability

\footnotetext{
21 As discussed in the previous section, and given our assumption of a random walk process for technology, that optimal response could indeed be supported by a Taylor rule.

22 To approximate the observed path of productivity we set $\rho=0.7$ in our calibrated model.

23 Similar findings were obtained by Galí (1999) and Basu, Fernald and Kimball (1998).
} 
implied by the optimal policy. Formal evidence of the significance of the deviations in hours and inflation from their optimal path is shown in Figure 7.

Underlying those results is the response of real interest rate. The latter lies above the optimal response at most horizons which might explain the gap between the actual and optimal output responses. Even though the nominal rate is shown to decline in response to the shock, the size of the reduction falls short that of inflation, which translates into a persistently higher real rate. In other words, changes in nominal rate are insufficient to counteract the effect of technology shock on inflation. ${ }^{24}$

We find it worth stressing here that the allowance for capital accumulation would hardly help reconcile the estimated response of hours for the pre-Volcker period with one consistent with the optimal policy. Indeed, for standard calibrations of the capital-augmented model, the response of hours to a technology shock has the opposite sign to the one estimated for that period (i.e., the model predicts that hours should increase in response to a positive technology shock) ${ }^{25}$

A comparison of the estimated responses for the pre-Volcker period and those generated by the money rule (see Figures 2 and 4) may be suggestive of some qualitative similarities. In particular, both imply an excessively tight policy in response to a positive technology shock, which tends to destabilize hours and inflation (while over-stabilizing output). In order to assesss empirically the plausibility that the Fed followed a monetary targeting rule (conditional on technology shocks) we have also estimated our VAR for the pre-Vocker period including M1 and M2 growth as additional variables. Figure 8 displays the estimated response of those monetary aggregates (in growth rates and levels) to our identified technology shock. As the Figure clearly shows, we detect a significant deviation from a policy that sought to insulate the path of monetary aggregates from the effects of the shock. That evidence thus calls into question the tentative interpretation given above,

\footnotetext{
24 This is consistent with the estimates of the unconditional interest rates rule for the same period obtained by Clarida, Galí and Gertler (2000).

25 Nevertheless, it is possible to generate a short run decrease in hours in the face of a positive technology shock under a calibration of preferences implying a sufficiently strong wealth effect (i.e., a high $\sigma$ ). See, e.g., Rotemberg and Woodford (1996).
} 
and is not in disaccord with descriptions of monetary policy in the pre-Volcker period as one characterized by frequent misses of monetary targets. ${ }^{26}$

\section{Conclusions}

In this paper we have estimated the Fed's systematic response to technology shocks and its implications for U.S. output, hours and inflation. The analysis of that evidence allows us to evaluate the extent to which the Fed has sought to stabilize prices in response to such shocks, as would be prescribed by the optimal policy in an environment in which the presence of staggered price setting is the main distortion to be corrected by the monetary authority. Our key results can be summarized as follows. First, we detect significant differences across periods in the response of the economy (as well as the Fed's) to a technology shock. Second, the Fed's response to a technology shock in the Volcker-Greenspan period appears to be consistent with a rule that seeks to stabilize prices and the output gap. Third, estimates for the pre-Volcker period suggest that the Fed's policy tended to over-stabilize output, thus generating excess volatility in inflation. Our evidence reinforces recent results in the literature suggesting an improvement over the postwar period in the way the Fed has conducted monetary policy.

${ }^{26}$ See, e.g., Meulendyke (1990). 


\section{REFERENCES}

Andrés, Javier; David López-Salido and Javier Vallés (1999): "Intertemporal Substitution and the Liquidity Effect in a Sticky Price Model," Bank of Spain Working Paper 99-19 (forthcoming in the European Economic Review)

Basu, Susanto; Fernald, John and Miles Kimball (1997): "Are Technology Improvements Contractionary?," University of Michigan, 1997.

Bernanke, Ben and Ilian Mihov (1998): "Measuring Monetary Policy," Quarterly Journal of Economics, 113, 869-902.

Bullard, James, and Kaushik Mitra (2001): "Learning About Monetary Policy Rules," Journal of Monetary Economics, forthcoming.

Calvo, Guillermo A. (1983): "Staggered Prices in a Utility Maximizing Framework," Journal of Monetary Economics, 12, 383-398.

Clarida, Richard, Jordi Galí, and Mark Gertler(2000): "Monetary Policy Rules and Macroeconomic Stability: Evidence and Some Theory," Quarterly Journal of Economics, 115, 147-180.

Christiano, Lawrence, Martin Eichenbaum and Charles Evans (1997): "Sticky Price and Limited Participation Models: A Comparison," European Economic Review, 41, 1201-1249

Dotsey, Michael (1999): "Structure from Shocks," mimeo, Federal Reserve Bank of Richmond.

Galí, Jordi (1999): "Technology, Employment, and the Business Cycle: Do Technology Shocks Explain Aggregate Productivity," American Economic Review, 89, 249-271.

Galí, Jordi and Mark Gertler (1999): "Inflation Dynamics: A Structural Econometric Analysis," Journal of Monetary Economics, vol. 44, no. 2, 195-222.

Galí, Jordi and Tommaso Monacelli (1999): "Optimal Monetary Policy in A Small Open Economy," mimeo.

Galí, Jordi (2000): "New Perspectives on Monetary Policy, Inflation and the Business Cycle," mimeo. 
Goodfriend, Marvin and Robert G. King (2001): "The Case for Price Stability," in GarciaHerrero et al. (eds.) Why Price Stability? European Central Bank, 53-94.

Judd, John P. and Glenn D. Rudebusch (1999):" Taylor's Rule and the Fed: 1970-1997," Federal Reserve Bank of San Francisco Economic Review, 3, 3-16.

McGrattan, Ellen R. (1999): "Predicting the Effects of the Federal Reserve Policy in A Sticky-

Price Model: An Analytical Approach," Federal Reserve Bank of Minneapolis Working Paper 598, December.

Meulendyke, Ann-Marie (1990): "A Review of Federal Reserve Policy Targets and Operating Guides in Recent Decades," in Intermediate Targets and Indicators for Monetary Policy: A Critical Survey, Federal Reserve Bank of New York, 1990.

Rotemberg, Julio, and Michael Woodford (1999), "Interest Rate Rules in An Estimated Sticky Price Model," in Monetary Policy Rules, John B. Taylor (ed.), The University of Chicago Press, $57-119$

Taylor, John B. (1993): "Discretion versus Policy Rules in Practice," Carnegie-Rochester Conference Series on Public Policy, 39, 195-214.

Taylor, John B. (1999): "Introduction," in Monetary Policy Rules, John B. Taylor (ed.), The University of Chicago Press, 1-14.

Woodford, Michael (1996): "Control of the Public Debt: A Requirement for Price Stability," NBER Working Paper 5684.

Woodford, Michael (2000): "A Neo-Wicksellian Framework for the Analysis of Monetary Policy," unpublished manuscript.

Woodford, Michael (2001): "Inflation Stabilization and Welfare," NBER WP\#8071.

Yun, Tack (1996): "Nominal Price Rigidity, Money Supply Endogeneity, and Business Cycles," Journal of Monetary Economics, 37, 345-370. 


\begin{tabular}{|c|c|c|c|c|c|}
\hline Equation & & Own Lags & Other Lags & $R^{2}$ & DW \\
\hline \multirow[t]{2}{*}{ Labor Productivity } & Pre-Volcker & 0.02 & 0.00 & 0.49 & 1.97 \\
\hline & Volcker-Greenspan & 0.20 & 0.15 & 0.43 & 1.92 \\
\hline \multirow[t]{2}{*}{ Hours } & Pre-Volcker & 0.00 & 0.20 & 0.94 & 1.98 \\
\hline & Volcker-Greenspan & 0.00 & 0.01 & 0.96 & 1.95 \\
\hline \multirow[t]{2}{*}{ Real Interest Rate } & Pre-Volcker & 0.30 & 0.20 & 0.60 & 1.96 \\
\hline & Volcker-Greenspan & 0.00 & 0.03 & 0.89 & 1.96 \\
\hline \multirow[t]{2}{*}{ Inflation } & Pre-Volcker & 0.00 & 0.00 & 0.95 & 1.99 \\
\hline & Volcker-Greenspan & 0.00 & 0.60 & 0.90 & 1.95 \\
\hline
\end{tabular}

Note: Values in the third and fourth columns are p-values for the F tests. The PreVolcker period corresponds to 1954:2-1979:3; and the Volcker-Greenspan period corresponds to 1982:4-1998:4. 


\section{Figure 1. The D ynamic Effects of Technology Shocks Optimal Podicy versus Taylor Rule}
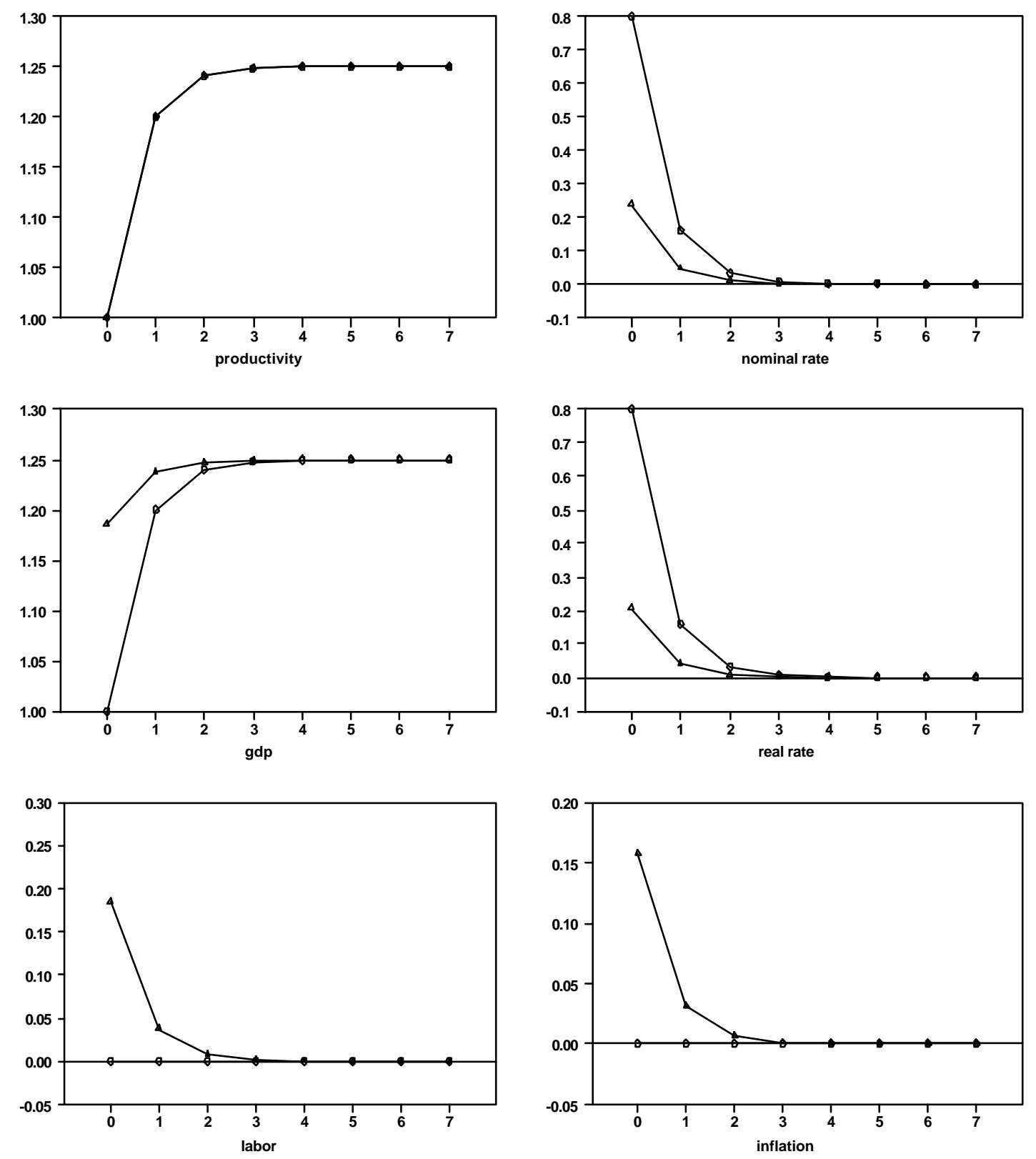

Note: Response to a permanent increase in total factor productivity. Lines with circles correspond to the responses under the optimal policy. Lines with triangles represent the responses under the Taylor rule described in the text. 


\section{Figure 2. The D ynamic Effects of Technology Shocks Optimal Policy versus M oneary Targeting Rule}
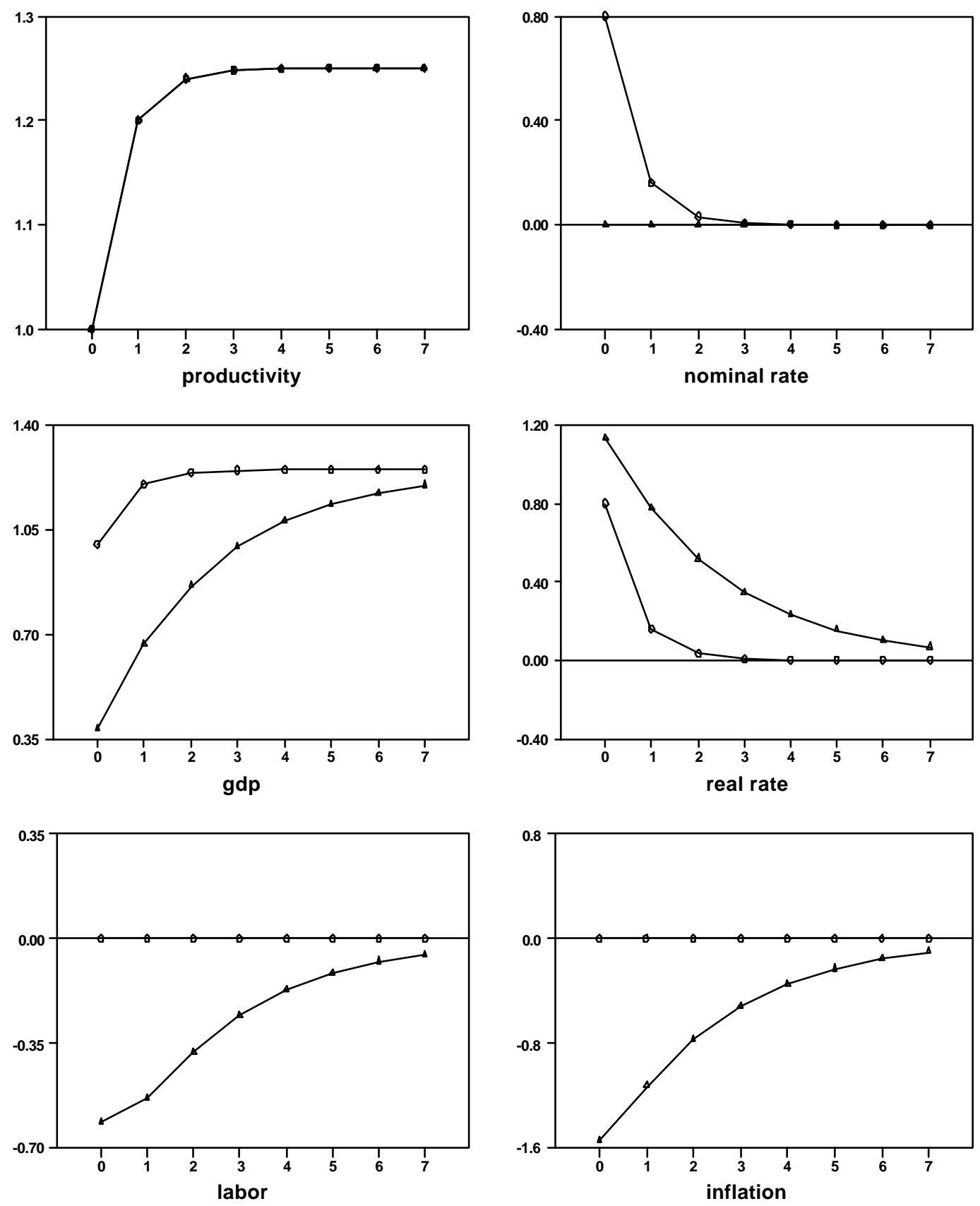

Note: Response to a permanent increase in total factor productivity. Lines with circles correspond to the responses under the optimal policy. Lines with triangles represent the responses under a constant money growth rule. 


\section{Figure 3. VAR-based versus BFK Technology Shocks}

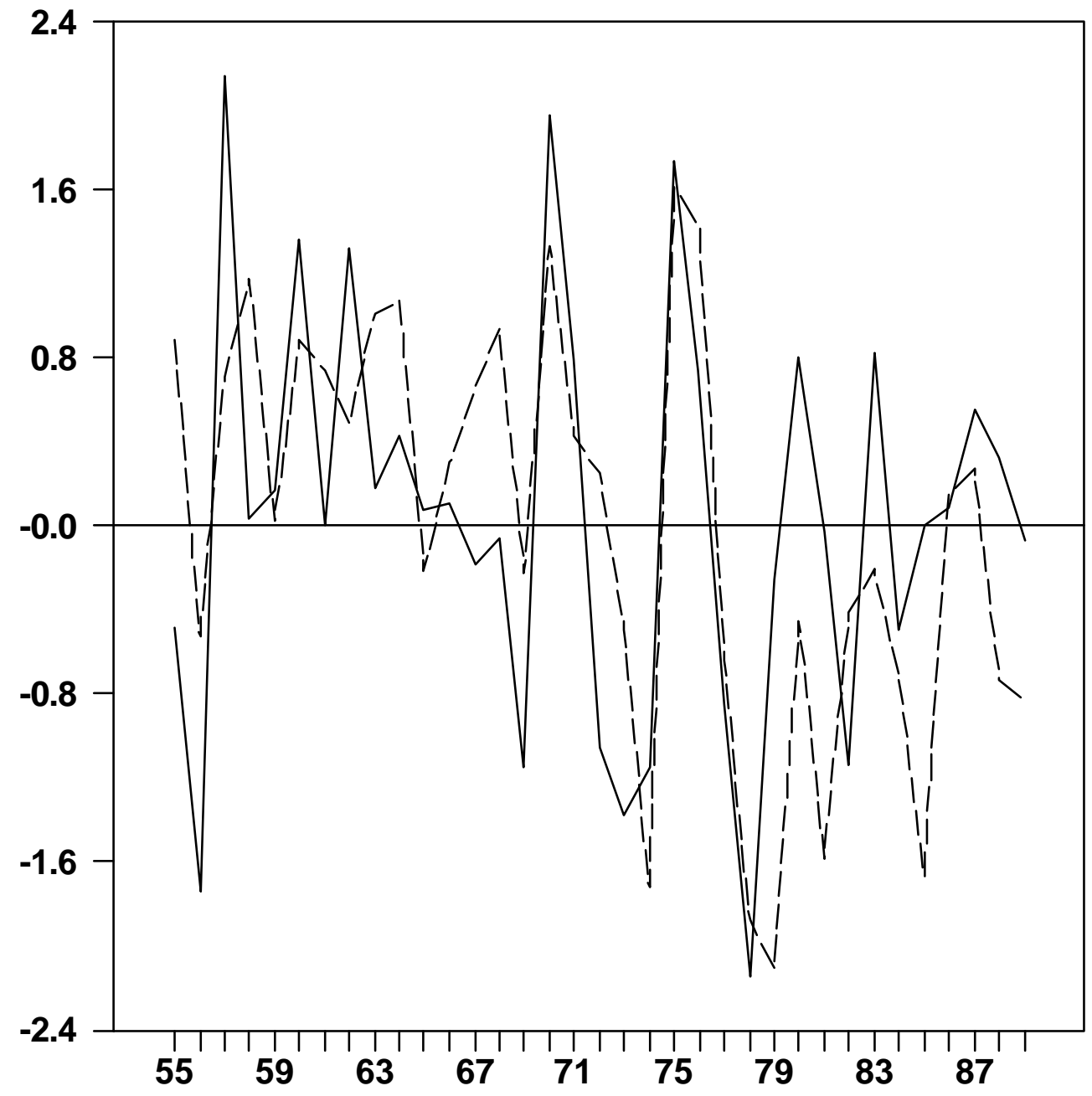

Note: The solid line represents the estimated technology sh ock implied by the VAR. The dashed line corresponds to the technology shock series constructed by Basu, Fernald and Kimball (1999). 


\section{Figure 4. The D ynamic Effects of Technology Shocks Voldker-Greenspan Period}
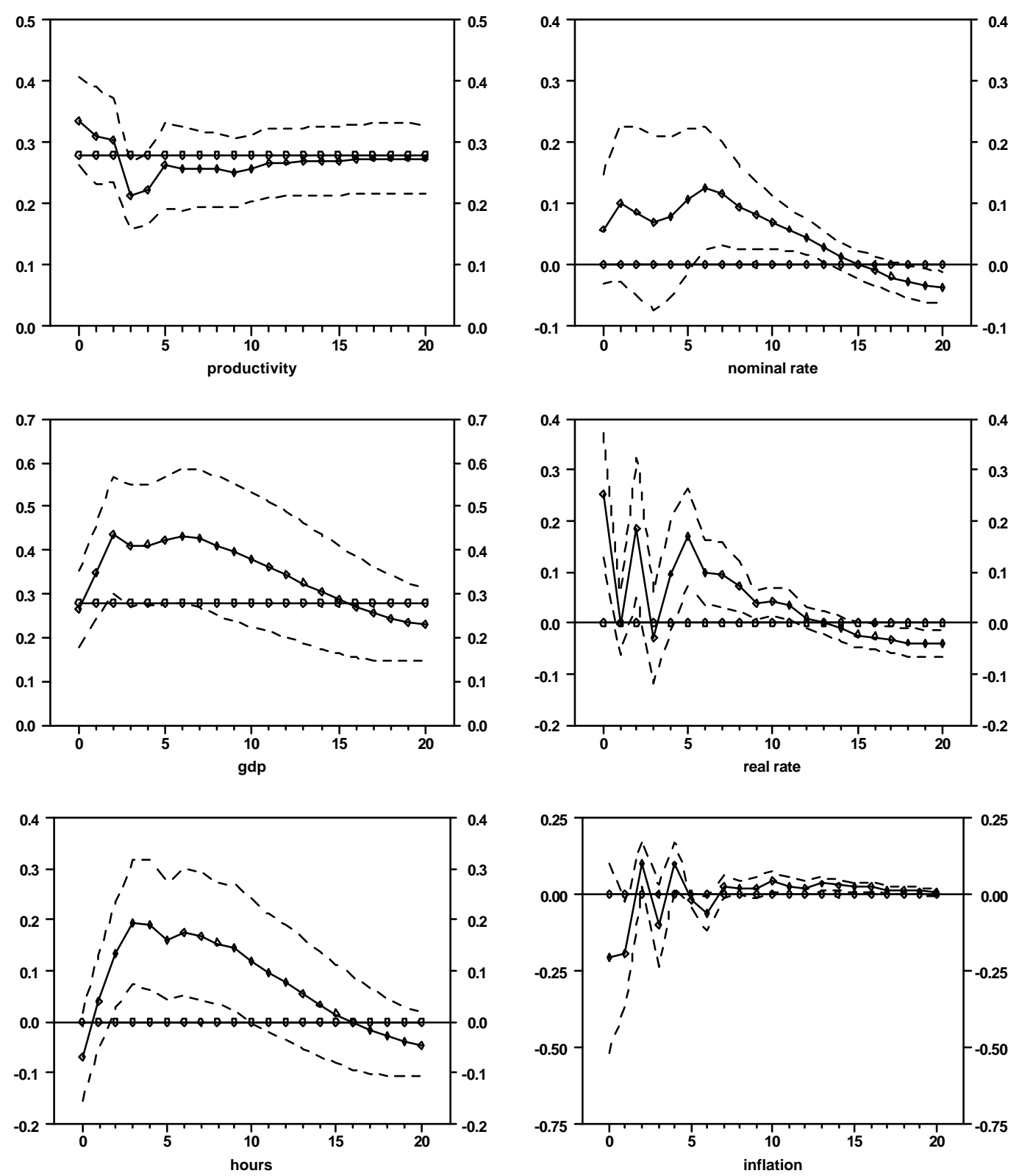

Note: Estimated impulseresponse functions to a technology shock for the Volcker-Greenspan period, with corresponding $95 \%$ confidence intervals. The line with circles represents the corresponding responses under the optimal policy. 
Figure 5. Testing the 0 ptimality Hypothesis

Voldker-Greenspan Period
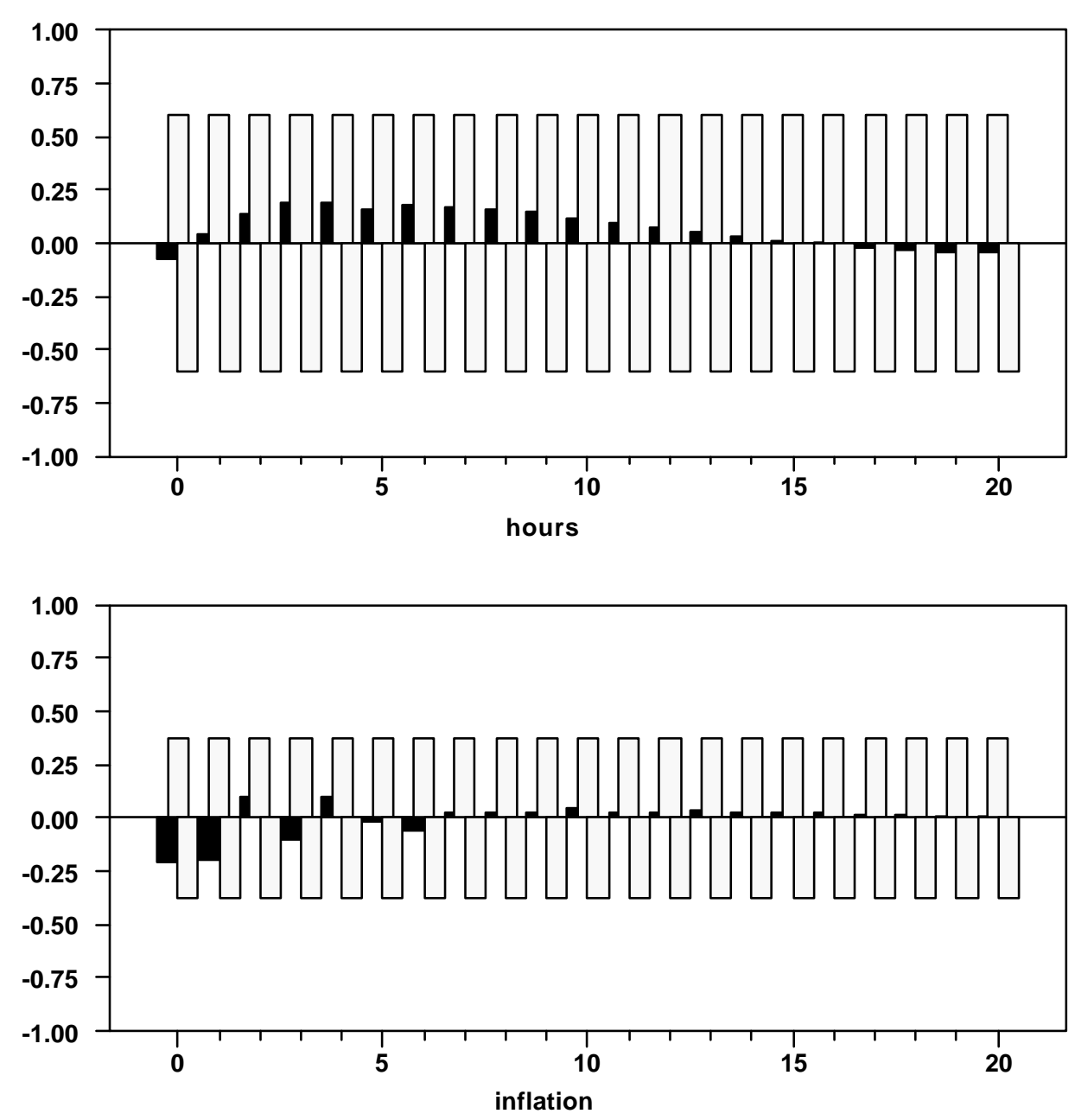

Note: Dark bars show the estimated impulse-responses of each variable to a technology shock for the Volcker-Greenspan period. White bars are the corresponding $95 \%$ confidence intervals for the null hypothesis of a zero response. 


\section{Figure 6. The D ynamic Effects of Technology Shocks PreVolcker Period}
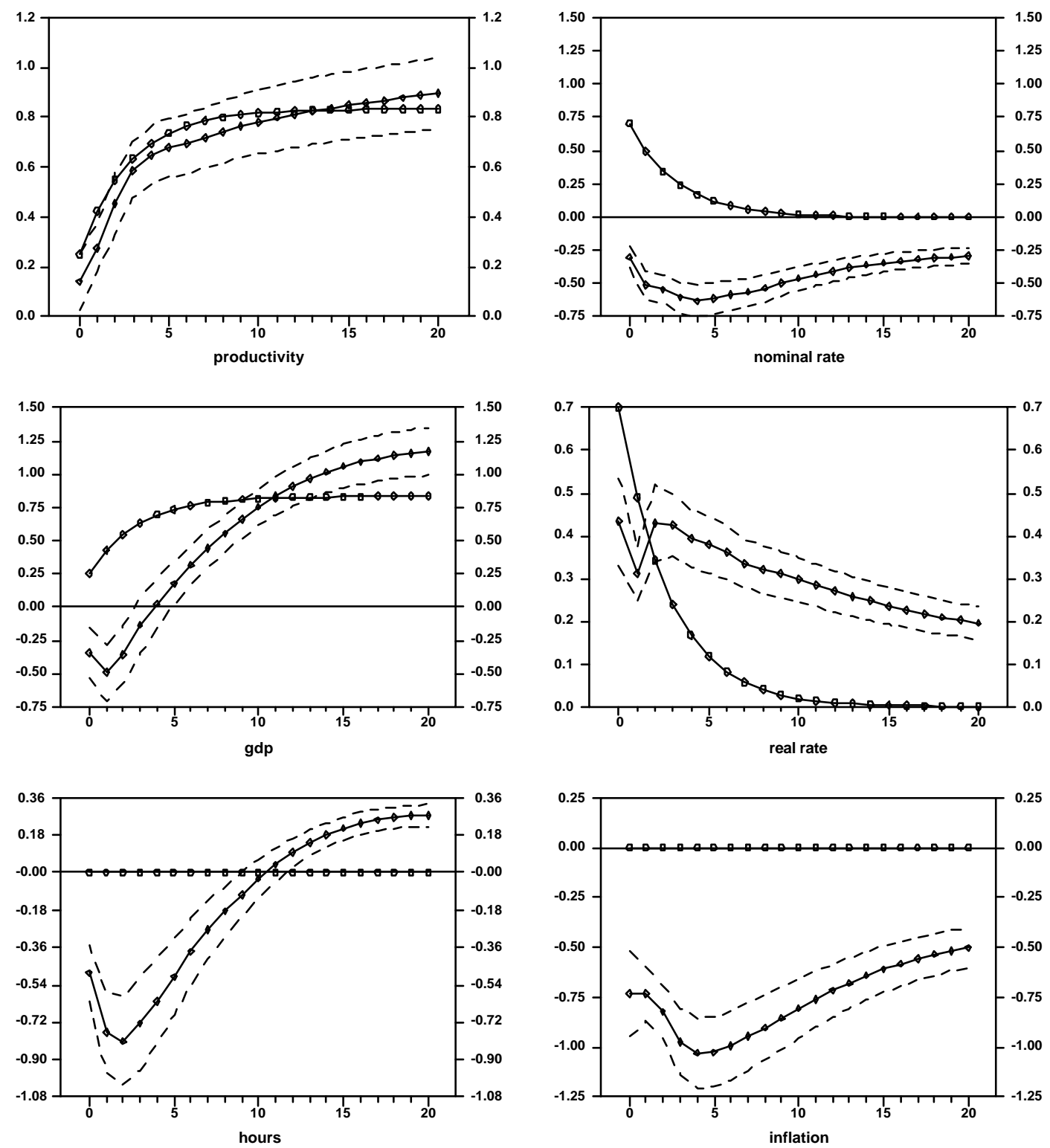

Note: Estimated impulseresponse functions to a technology shock for the preVolcker period, with the corresponding 95\% confidence intervals. The line with circles represents the corresponding responses under the optimal policy. 
Figure 7. Testing the O ptimality Hipótesis PreVoldker Period
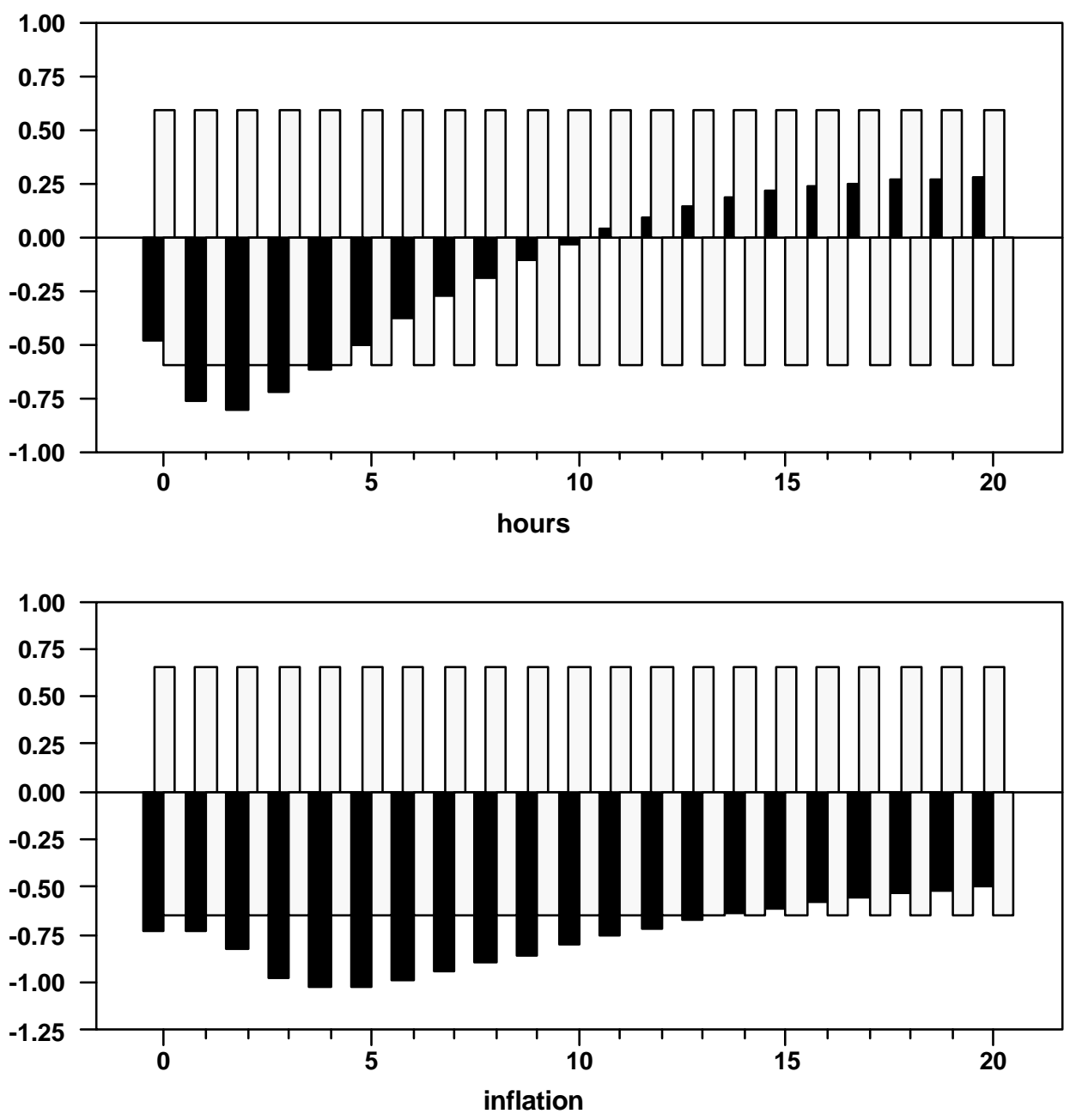

Note: Dark bars show the estimated impulse-responses of each variable to a technology shock for the pre-Volcker period. White bars are the corresponding $95 \%$ confidence intervals for the null hypothesis of a zero response. 
Figure 8. Responses of M onetary Aggregates to a Technology Shock in the Pre-V olcker Period

M1
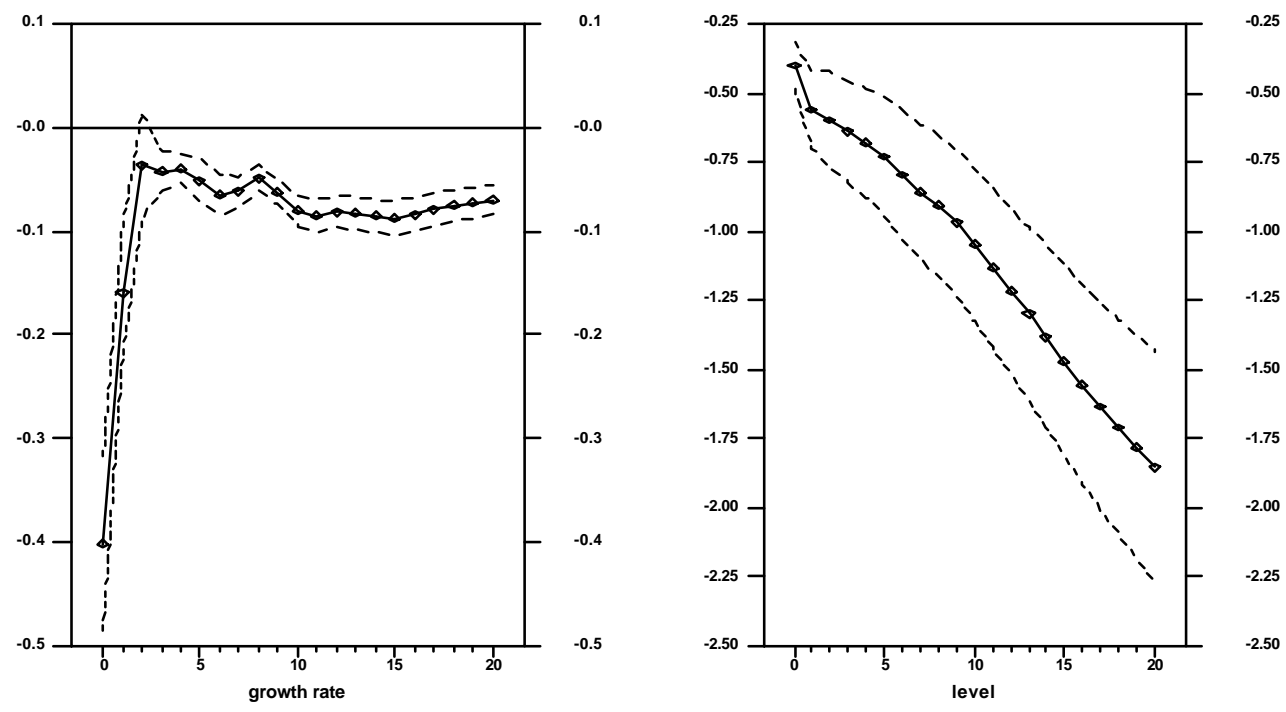

\section{M2}
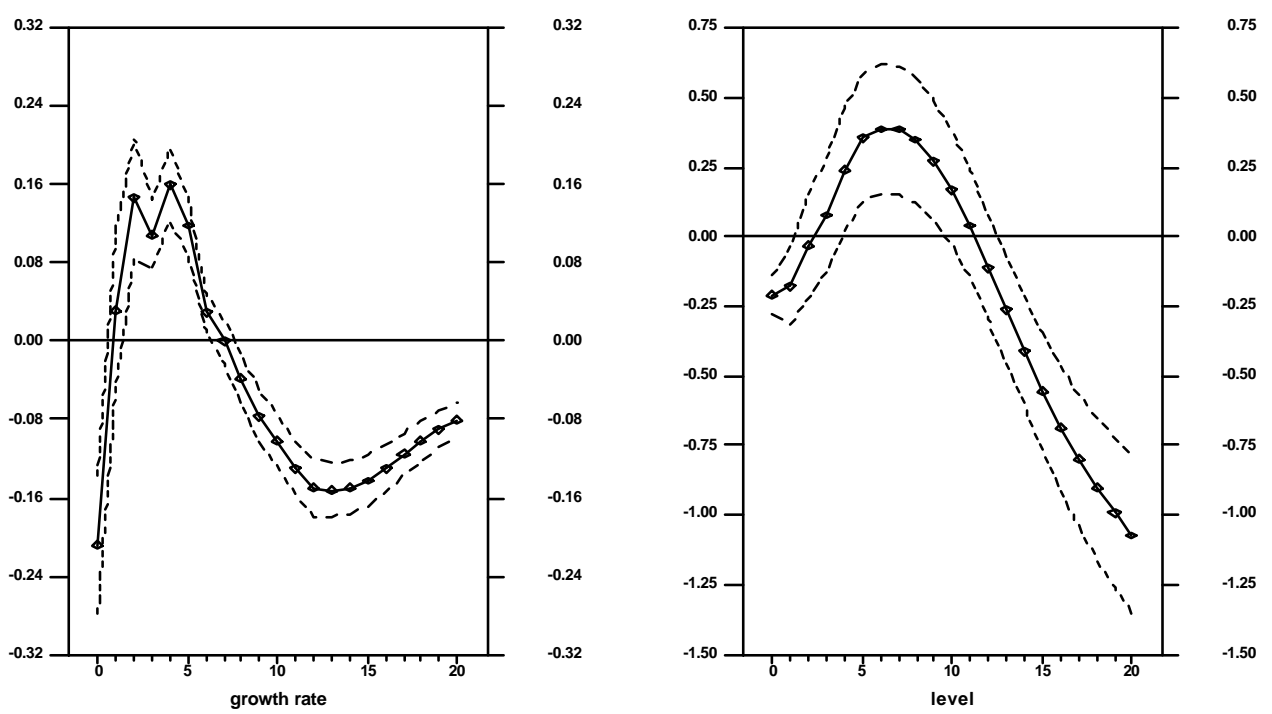

Note: Estimated impulse-responses of $\mathrm{M} 1$ and $\mathrm{M} 2$ to atechnology shock for the pre-Volcker period, with the corresponding 95\% confidence intervals. 